\title{
EDUCATIONAL
}

TECHNOLOGY

\section{Distance education or education at a distance}

\author{
Paul Rixon \\ Educational Technology Centre \\ Education Department of South Australia
}

In a state such as South Australia, many primary and secondary students study far from their teachers. There are various reasons for this such as the geographic isolation of students or the inability of many schools to timetable teachers for all of the curricula required by their students. The term 'distance education' is used to describe perhaps the best known and most widely written about alternative strategy to the classroom. However, there is a much younger strategy which relies heavily on the use of newer technologies. This has been called 'education at a distance' to distinguish between the two.

Distance education has been defined as: 'a purposeful and deliberate learning activity, planned, structured and negotiated by a teacher; received and controlled by a learner who is operating in a non-contiguous mode for most of the time'.' This definition immediately restricts the options available to an educational program. Indeed some writers, such as Baath, consider 'pure' distance education to use only non-immediate media. (2)

The pure distance education described by Baath is usually characterised by the use of mail delivered print media. As a result, the process of communication between tutor and student will require lengthy periods. The learning package, therefore, is usually fairly structured and large, to attempt to cope with the widest possible range of student responses. The structure may be complex in order to address individual differences, but is almost always pre-determined. Packages such as these are time consuming to prepare and expensive to print unless printed in large quantities. Often the tutor is not the author of the package.

Communications technology is able to provide a mechanism which can allow many of the normal classroom patterns of information flow to be replicated in a non-face-to-face situation. Thus a learning system can be defined where the learner is able to have immediate communication and interaction with a teacher and other learners not physically present. Unlike 
distance education, with education at a distance, significant reliance is placed on immediate interaction between the teacher and student(s). Most of the differences in philosophy and practice between the two systems is derived from this contrast.

Writers such as Holmberg have stated that 'education is based on communication between educans and educandus and, in most cases, on peer group interaction'. (3) In order to apply this philosophy to distance education, Holmberg then suggests that the presentation of learning matter in a printed or otherwise pre-produced course. . represents a kind of simulated communication'. (4) Educators have long held that simulations are a valuable part of education but does it not seem a pity to restrict oneself to a simulation when the real thing is available?

As already mentioned, traditional, pure distance education has relied extensively upon printed media to communicate to the students. This approach then, contrasts sharply with classroom strategies currently being implemented as a result of concerns about the reading ability of many students. As a result, it could be expected poor readers would find distance education more demanding than the classroom.

With education at a distance, information flow can take place through a varied range of options and in particular through normal conversation. This relieves the younger student and the poorer reader from the tedium and/or danger of coping with many instructions. This also allows for simple feedback or checking activities to ensure the student does not stray too far from the intentions of the lesson plan.

The reliance upon printed media is only one way in which distance education programs may pressure students. Even tertiary students find the grind of distance education forbidding. Many studies have concentrated on drop-out rates as a measure of the success of the program. Some tertiary studies have shown that the drop-out rates can be as high as 50 per cent after 12 months and that as many as 10 per cent of the students may never submit even one assignment. (5) When these figures are compared with the pre-tertiary situation the expected success rate would be even lower. Those students are frequently enrolled because they are still compelled to attend a school and have lower motivational, selfdiscipline and skill levels.

Several studies have indicated that the complexity of the learning package can be greatly reduced if significant interaction periods are provided. Data from one study by Sparkes (6) gives a comparison between programs using various teaching methodologies and the effort required to set up and run those programs (see table 1). Negotiations required to meet the individual needs of students can be easily supplied in interactive systems. This means the task of producing the package can be reduced and with this comes a lessening of the industrialisation of education. 
Table 1: Effective Use of Manpower

\begin{tabular}{lc} 
Teaching Method & $\begin{array}{c}\text { Ratio of Academic man-hours per } \\
\text { student hour of work generated }\end{array}$ \\
\hline Lecturing & $2-10$ \\
Small Group Teaching & $1-10$ \\
Teaching by Telephone & 210 \\
Video-tape lectures (for TVI) & $3-10^{*}$ \\
Audio-vision & $10-20^{*}$ \\
Teaching text & $50-100^{* *}$ \\
Broadcast TV & 100 or more ${ }^{* *}$ \\
Computer-aided learning & 200 or more* \\
Interactive video-disc & 300 or more \\
& ${ }^{*}$ requires support staff \\
& ${ }^{* *}$ requires several support staff \\
\hline
\end{tabular}

The Open University, which has a much more vigorous system of supporting the students and provides more facilities for interaction between staff and students, has obtained much higher graduation rates than normal distance education courses. Holmberg notes that 'empirical studies have shown conclusively that there is a distinct correlation between turn-around time, i.e. the time elapsing between students' dispatch of assignments completed and their return - and course completion'. (7) He also states that 'telephone tutoring led to increased interest in the subject studied'. (8) Case studies and reports of telephone teaching programs in South Australian Schools support these statements: many students remarked that the course had become more interesting since telephone calls had been initiated. Enrolments for subjects increased after teaching by telephone had begun.

Sewart, in discussing the importance of peer-group communications with particular reference to the classroom, maintains that the 'group learning situation is itself supportive of the learning process, not only because of the potential interaction between students in relation to the academic content of the course - learning through discussion with one's peers - but also because the group learning offers a bench mark to the individual members of the group'. (9)

In South Australia, several trials have been carried out to assess the ability of media, such as the telephone, to use group learning processes. The results indicate that the introduction of immediate group interaction has enabled peer relationships to develop and group processes have become a normal part of the learning process. This has been shown to be true for a wide range of ages, from Junior Primary to Upper Secondary. (10)

Although the technology of the telephone (and associated equipment) is still capable of considerable refinement, it is interesting to note Robinson's claim that 'in general, the research shows that learning can take place as effectively, and in some cases, more effectively, on courses taught by telephone as on courses taught by other means' (the usual comparison is with face-to-face).' (11) 
It would seem that the processes of education at a distance, with immediate interaction between teacher and a group of students, should have an increasingly important part to play in the provision of educational opportunity in a system with many isolated students.

It is critical that the process of education at a distance should be available for young isolated students. These students should not be left with a strategy which is less than appropriate given their age and the technologies now available.

\section{References}

1. Steering Committee Report to the Senior Executive of South Australian Education Department: Distance Education, p15.

2. Baath, J. A list of ideas for the construction of distance education courses. In Stewart, D., Keegan, D. and Holmberg, D. (eds) Distance Education: International Perspectives, London, Croom Helm.

3. Holmberg, B. Guided Didactic conversation in distance education. In Sewart, D. et al: Distance Education: International Perspectives, London, Croom Helm, p114.

4. ibid p116.

5. Rekkedal, T. Research and development activities in the field of distance study at NKI-Skolen, Norway. In Sewart, et al Distance Education: International Perspectives, London, Croom Helm.

6. Sparkes, J. Pedagogic differences between media. In Bates, A. (ed) The Role of Technology in Distance Education, p219, London, Croom Helm.

7. Holmberg, B. Student Support Services. In Sewart et al Distance Education: International Perspectives, p322.

8. ibid.

9. Sewart, D. Distance Teaching.

10. Distance Education and Communication Trials, Status Report, Nov 1984, Educational Technology Centre, Adelaide.

11. Robinson, B. Telephone Teaching. In Bates, A. (Ed), The Role of Technology in Distance Education, p129, London, Croom Helm.

Please cite as: Rixon, P. (1985). Distance education or education at a distance. Australian Journal of Educational Technology, 1(2), 14-17. http: / / www.ascilite.org.au/ajet/ajet1/ rixon.html 